\title{
Land Degradation and Its Control
}

\author{
Q. ZHAO \\ Institute of Soil Science, Academia Sinica, Nanking (China)
}

Land degradation is one of the most important problems facing the globe, affecting the very fabric of mankind and the global environment. In China, the extent and impact of land degradation on the utilization of natural resources, environmental deterioration, and the yields achieved in agriculture, forestry and animal husbandry are now even greater than before. Therefore, a consideration of the whole globe, and studies on land degradation and on its prevention and control in China, will have great significance both for theory and practice.

\section{General Aspects of Land Degradation}

Land degradation is an outcome of depletive human activities and their interaction with natural land resources. Generally speaking, land degradation is defined as the process of decline in land quality through its misuse by humans. It may be a cause for concern for at least three reasons.

First, land degradation undermines the productive capacity of the ecosystem. Second, it affects the global climate through alterations in water and energy balance and disruptions in the carbon $(\mathrm{C})$, nitrogen $(\mathrm{N})$, sulphur $(\mathrm{S})$ and phosphorus $(\mathrm{P})$ cycles. Third, land degradation leads to political and social instability, an enhanced rate of deforestation, soil erosion, the pollution of natural waters, and the emission of greenhouse gases into the atmosphere, etc. Historical records have shown that most ancient civilizations, such as Egypt, India, as well as other countries, flourished on fertile soils, while land degradation was responsible for the extinction of cultivations in western India, western Asia and Central America. The statistics gathered by FAO/UNEP in 1986 pointed out that over the millennia as much as two billion hectares of land have been rendered unproductive through soil degradation. Furthermore, the current rate of land degradation is estimated at five to six million hectares per year, and if these statistics are even approximately correct, almost one third of the total arable land is likely to be destroyed by the turn of the century. If no effective conservation measures are taken, the grain output of 117 developing countries in the world will decrease by as much as $19 \%$ on average. By the end of this 
century, the South-eastern Asian region will only be able to feed $85 \%$ of its estimated population.

China is an old agricultural country with a long history. By means of radio carbon dating, the carbonized grains excavated from the Xian Banbo site were identified as being remains of 6000 years ago and the traces of carbonized rice grains unearthed in the Hemudu site in Zhejiang Province are believed to be 7000 years old. The application of lime in the flooded calcareous paddy soils in southern China dates back to over 1600 years. this is convincing evidence for several thousand years of human activities in China, enhancing the process of land evolution. On the other hand, the contradictions between increasing population pressure and land decrease, and the inappropriate utilization of land by human beings have made land degradations a considerable problem. There are about 33 million hectares in China which are mid-yielding, low-lying, and affected by salt and alkali, dry wind and sand, loss of soil and water, etc. Each year the occupation of arable land accounts for 6.6 million hectares, while 20 million hectares of cultivated land, affected by fertility depletion, decreases by $30 \%$ annually. All these mentioned above are obviously distinctive compared to global land degradation. This is a severe threat to utilization of land facing China which remains as an urgent problem to be solved immediately.

\section{Types of Land Degradation}

The core of land degradation is soil degradation. According to international studies and Chinese practice, the processes of soil degradation in China can be divided into three principal types: physical, chemical and biological.

(1) Physical degradation of the soil includes erosion and desertification, compaction and hardsetting as well as laterization. Soil erosion represents the most complete form of land degradation, which is caused by human activities, nutrient depletion and excessive leading. The statistics show that the area of arable land affected by erosion in the world amounts to 25 million $\mathrm{km}^{2}$, constituting $27 \%$ of the total land area. The yearly loss of land suffering from erosion amounts to 6-7 million hectares. In general, soil erosion can be divided into water and wind erosion. In China soil water erosion is mainly found in the Loess Plateau, North-western China, in hilly-mountainous regions, and in Southern China. With an area of 1.5 million $\mathrm{km}^{2}$, it occupies $1 / 6$ of the total cultivated land area of the country. This means that 5 billion tons of soil are destroyed every year, almost equal to 1.5 million hectares of farming land runoff. Wind erosion is considered in association with the process of desertification. The arid and semi-arid regions of China include 11 provinces, with an area of 1.49 million $\mathrm{km}^{2}$, of which the area of the cross bedding region of agriculture and animal husbandry directly affected by wind and desertification amounts to $330,000 \mathrm{~km}^{2}$. 
Compaction and hardsetting are processes of soil degradation that lead to a hard, structureless mass with very few pores because of unreasonable agricultural traffic or trampling and erosion conditions. In the Taiha Lake region of China, almost $80 \%$ of the paddy soils were found to be compact, after the cropping system in the region was altered to the triple cropping systems. In Northeast China hardsetting was identified in black earths under mechanical cultivation. Red soils in tropical and subtropical China also exhibited desilicification and a compacted layer due to improper farming cultivation and erosion.

(2) Chemical degradation of the soil involves soil elemental imbalances, acidification, sodication as well as chemical pollution. Soil elemental imbalance is caused by the depletion of soil nutrients due to the long-term cropping of cultivated land without appropriate management, resulting in a serious decline in soil fertility. After cultivation for 10 years with no fertilization, the total $\mathrm{N}$ content of black soils in Northeast China has declined from 0.33 to $0.26 \%$, which is likely to further decrease to $0.15 \%$ in the coming 50 years. Consequently, the yield of wheat will also decrease by 30 to $50 \%$. The other main causes of crop yield reduction and deterioration of the soil fertility are soil acidification, secondary salinization and toxic pollution.

(3) Biological degradation of the soil. A reduction in the soil organic matter content and a decrease in the activity and diversity of the soil macro- and microfauna are ramifications of biological degradation. Owing to the neglect of effective management, the 10-year reclamation of bog soils in China for crop cultivation has brought about a $30.64 \%$ reduction in organic matter, which will rapadily decline by $54.9 \%$ in the coming 50 years. The degradation of the soil fauna is more severe in the tropics than in the temperate zone. Biological degradation can also be caused by soil pollutants. Though China has abundant natural forest resources, the average coverage of forest per capita constitutes only $15 \%$ of the world average. The average coverage rate of forest over the whole territory is only $12 \%$. China has 40 million hectares of grasslands, of which about $30 \%$ have been seriously degraded. The output of animal products in China presents only $1 / 20$ of that of the United States.

\section{Land Degradation and Human Activities}

Water erosion in the Loess Plateau - The population in the Loess Plateau doubled from the 1950 s to the 1980 s, leading to over exploitation of the forests. The forest line on the Ziwu mountain has receded 20 kilometres. According to the statistics, whenever one person comes into the world, about 0.3 hectares of the land in the region must be reclaimed. About 100,000 kilometres of the slopes have been opened for cropping in the last 3 decades, leading to severe water erosion. Therefore, the amount of soil erosion has amounted to 1.3 billion 
tons to 2.2 billion tons over the last hundred years. Soil erosion not only hinders the development of production but also threatens human safety.

Wind erosion and desertification of interlocks of agriculture and pasture Since its foundation in 1949, China has seen up to one hundred million hectares of grasslands desertified in the semi-arid interlocking regions of agriculture and pasture, constituting one third of the total national grasslands. For example, Shangdu County of the Southern Wulanbu grassland was a virgin grassland one hundred years ago (1885). In the 20s of this century, transmigrants settled down in the area. By the 1980 s, both population and cultivated land increased four times while the area of grassland decreased by $50 \%$, with about $1 / 3$ of the arable land suffering from desertification, resulting in an area of $2100 \mathrm{~km}^{2}$ of land desertified annually. Nonetheless, the prevention of desertification is a major problem which is extremely serious and worthy of our immediate attention (Table 5).

Soil salinization of arid and semi-arid regions. - The North China Plain had about 250,000 hectares of salinized soils in the 1950 s. Due to irrational irrigation and cultivation, severe secondary salinization occurred, while the area of salinized soils rose to 4 million hectares. The salinization area of the Hetao region in Inner Mongolia increased by $43-47 \%$ in less than 20 years (from 1954 to 1974), while the saline soil spot area had an expansion rate of 1-3\% annually. Statistics indicate that China has an area of nearly 10 million hectares of salified soils, in which there are about 1.7 million hectares of soil in a state of potential salinization, amounting to $17.5 \%$ of the salified soils. The salified soils which cover nearly 1 million hectares of the arable land in China are great obstacles to the development of agriculture.

Degradation of soil fertility in farming areas. - The maintenance of the available nutrients in the soil is distinctly restricted in the cycling period; it takes 20 to 40 years for N, 10 to 20 years for P and 80 to 130 years for K. In Northeast China the organic matter contents of black soils have decreased by 1 to $2 \%$ after cultivation for around 10 years, and it would take 100 years to rebuild the organic levels in balance. The soil humic contents will be reduced by 30 to $60 \%$ in 10 years, with a decrease of $54.9 \%$ in 50 years.

Due to the improper raising of the multiple cropping index, the cultivated layer has become shallower and the plowpan heavier in some paddy soils in the Taihu Lake Region, South China, which brought about a decrease in rice yield of $50 \%$ (Tables 1, 2, 3).

Soil pollution. - Statistically, about 50 thousand hectares of land have become the final solution for $80 \%$ of the industrial waste disposal in China, including 8 thousand hectares of cultivated land. In addition, the land suffering from pesticidal toxics amounts to 1.3 million hectares. These human-induced 
Table 1

Variation of nitrogen content of soils under natural vegetation and cultivation

\begin{tabular}{lcc}
\hline Soils & $\begin{array}{c}\text { Natural } \\
\text { vegetation }\end{array}$ & $\begin{array}{c}\text { Cultivated land } \\
\text { (cultivated for } \\
\mathbf{2 0 0 - 5 0 0} \text { years) }\end{array}$ \\
\hline Black soil & $0.256-0.695$ & $0.150-0.348$ \\
Cinnamon soil, & & \\
Burozem & $0.064-0.145$ & $0.030-0.099$ \\
Red earth & $0.101-0.340$ & $0.050-0.115$ \\
Latosol & $0.090-0.305$ & $0.070-0.183$
\end{tabular}

Table 2

Composition of organic matter (\%) and nutrients (\%) in soils after cultivation

\begin{tabular}{llcccc}
\hline Soils & $\begin{array}{l}\text { Period of } \\
\text { cultivation }\end{array}$ & O. M. & $\begin{array}{c}\text { Total } \\
\text { N }\end{array}$ & $\begin{array}{c}\text { Total } \\
\text { P }\end{array}$ & $\begin{array}{c}\text { Total } \\
\text { K }\end{array}$ \\
\hline Meadow soil & & & & & \\
(sand loam) & Waste land & 8.83 & 0.508 & 0.284 & 2.00 \\
& $\begin{array}{l}\text { Abandoned land } \\
\text { Land cultivated for }\end{array}$ & 7.76 & 0.439 & 0.261 & 2.06 \\
& 29 yrs & 6.83 & 0.228 & 0.238 & 2.12 \\
Black soil & Waste land & 6.31 & 0.268 & 0.175 & - \\
(sand loam) & Land cultivated for & & & & \\
Black soils & 20 yrs & 2.34 & 0.115 & 0.086 & - \\
& $\begin{array}{l}\text { Waste land } \\
\text { Land cultivated for }\end{array}$ & 7.09 & 0.335 & 0.133 & 2.30 \\
& $\begin{array}{l}\text { 10 yrs } \\
\text { Land cultivated for }\end{array}$ & 4.58 & 0.268 & 118 & 2.48 \\
& $\begin{array}{l}\text { 50 yrs } \\
\text { Waste land }\end{array}$ & 2.93 & 0.157 & 0.092 & 2.30 \\
Mashed & $\begin{array}{l}\text { Land cultivated for } \\
\text { Black soil }\end{array}$ & 5.84 & 0.352 & 0.183 & 2.26 \\
& $\begin{array}{l}\text { Land cultivated for } \\
\text { 50 yrs }\end{array}$ & 5.81 & 0.298 & 0.178 & 2.32 \\
& $\begin{array}{l}\text { Land cultivated for } \\
\text { 100 yrs }\end{array}$ & 5.19 & 0.278 & 0.164 & - \\
& & 4.11 & 0.210 & 0.137 & 2.28
\end{tabular}


Table 3

Variation in the composition of humus under black soils after cultivation

\begin{tabular}{lccccc}
\hline $\begin{array}{l}\text { Years of } \\
\text { land cul- } \\
\text { tivation }\end{array}$ & $\begin{array}{c}\text { Humus } \\
\%\end{array}$ & $\begin{array}{c}\text { Humic } \\
\text { acid } \\
\text { (H.a.), \% }\end{array}$ & $\begin{array}{c}\text { Fulvic acid } \\
\text { (F.a.) } \\
\%\end{array}$ & H.a/F.a. & $\begin{array}{c}\text { Active } \\
\text { humic } \\
\text { acid, \% }\end{array}$ \\
\hline Waste land & 5.97 & 1.20 & 0.75 & 1.60 & 0.55 \\
10 years & 4.14 & 0.74 & 0.39 & 1.90 & 0.30 \\
50 years & 2.69 & 0.60 & 0.40 & 1.50 & 0.41
\end{tabular}

products are increasingly diverse and many are potentially toxic to humans and to the environment.

Destruction of forest and grass. - There is $10.6 \%$ more deforestation than afforestation. The actual felling of the forest was $10 \%$ greater than the amount of growth, $43 \%$ higher than the felling plan. The area of degraded grassland has an annual rate of 61 thousand hectares.

Occupation of land. - The occupation of land is another severe problem involved in land degradation. In the 1950s the total cultivated land in China was 97 million hectares, and in 1982, the cultivated land amounted to 99.3 million hectares, although 21.3 million hectares had been reclaimed. The area occupied had reached as much as 460,000 hectares a year. So, by the end of this century, instead of an increase, the cultivated land will be reduced by 12 million hectares, and will amount to only 0.06 hectares per capita. Though soil productivity can be improved, the productive potential of land resources is finite. The occupation of land may result in the destruction of productive facilities. The problem will become very severe if the conflict between increasing population and decreasing land remains unsolved.

\section{The Prevention of Land Degradation}

\section{Comprehensive management in line with local condition}

Comprehensive measures should be taken combining land resources, biological deposits and environmental factors.

Firstly, comprehensive measures should be adopted for the disposal and utilization of soils in regions where the natural balance of the ecosystem has been destroyed. For example, in the loessal region of the Northwest Plateau, water and soil conservation should be emphasized in combination with extensively seeding grasses and afforestation, and reasonable cultivation of the agricultural soils should be adopted for increasing the crop yield per unit area, while the 
reclamation of steep slopes should be strictly forbidden. On the Huang-HuaiHai plain in North China the fertility of the soils should be improved and multiple cropping should be promoted on the soils. In the hilly-mountainous regions of South China the comprehensive exploitation of agriculture, forestry, pasture and the cultivation of economic crops should be emphasized, based on the prevention and control of soil erosion. In the interlocking regions of agriculture and pasture in North China, the prevention and control of wind erosion and desertification should be emphasized by means of comprehensive measures of afforestation (including arbour and shrub forests) or seeding grasses, while the ploughing up of grassland for cropping should be forbidden. In the tropical region, more attention should be paid to improving natural reserves and to vertical layouts of different kinds of crops. Secondly, the rational disposal and specialization of agriculture should be adopted according to regional bioclimatic conditions. East China is the region of agriculture while West China is the region of pasture, based on the regional characters. In addition, agricultural production should be gradually divided or distinguished into different specialized regions of agriculture, pasture or forestry, namely, by the adoption of intensive agriculture. thirdly, the comprehensive management of agriculture, forestry, pasture and fisheries should be emphasized, based on capital construc-

Table 4

Changes in soil salinization along the natural Weny Channel Valley (in hectares)

\begin{tabular}{cccc}
\hline Year & $\begin{array}{c}\text { Area of lightly } \\
\text { salinized soil }\end{array}$ & $\begin{array}{c}\text { Area of heavily } \\
\text { salinized soil }\end{array}$ & Total \\
\hline 1957 & 3458 & 12946 & 47527 \\
1961 & - & - & 100933 \\
1966 & 47526 & 15471 & 62727 \\
1984 & 38919 & 2991 & 412910
\end{tabular}

Table 5

Area affected by various forms of desertification in North China

\begin{tabular}{lcc}
\hline Causes of desertification & $\begin{array}{c}\text { Area } \\
\mathbf{k m}^{\mathbf{2}} \mathbf{)}\end{array}$ & $\begin{array}{c}\text { Total area } \\
(\%)\end{array}$ \\
\hline Over-cultivation & & \\
Over-pasturing & 4.47 & 25.4 \\
Over-felling & 4.99 & 28.3 \\
Construction work in the field of & 5.60 & 31.8 \\
industry, mining, communication & & \\
Lack of water conservation & 0.13 & 0.7 \\
Sand dunes moving (forward) & 1.47 & 8.3 \\
& 0.94 & 5.5
\end{tabular}


tion of farmland such as soil improvement and water control, as well as the establishment of an effective agroecological system step by step, so as to keep land degradation under control in an all-round way.

\section{Summary and extension of experience}

Based on the experience obtained through the prevention of land degradation, comprehensive prevention and control should be aimed at various patterns of land degradation, which should be gradually extended into different regions.

\section{Control of desertification. -}

Experience has shown that desertification can be prevented through control. The area of running sand in the Keerxin Region of Inner Mongolia was 1000 hectares in 1984, the forest coverage less than $10 \%$ and the total grain yield $15,000 \mathrm{~kg}$. In 1988, after 4 years of control, the area of running sand had dropped to less than $1 / 3$, while the grain yield had increased by $250,000 \mathrm{~kg}$. In the Maowushu Region, the area of desertification declined by $12 \%$ after 5 years of control, and the grass output increased by $240 \mathrm{~kg} / \mathrm{ha}$ to $1320 \mathrm{~kg} / \mathrm{ha}$. Starting in the Eight-Year Planning Period (1991-1995), 8 demonstration zones will be set up aimed at studying the process of land desertification and the comprehensive ecological systems of sandy land and grassland, whereby it is hoped to increase the coverage of forest and grass by $100 \%$ in the major forest areas, with an increase of $50 \%$ in the output value of agriculture and pasture, and a 30-40\% decrease in running sand. The per capita income will be as high as the national average.

\section{Control of erosion. -}

Due to the control of desertification, conducted at 11 experimental demonstration zones in the loess areas, the grain output of these experimental demonstration zones has now become basically self-sufficient, at $400-500 \mathrm{~kg}$ per capita, with a $13 \%$ increase per capita income, while the runoff volume of running sands decreased by $50 \%$, and the erosion inde $x$ of steep slopes declined by $45-90 \%$. During the Eighth Five-year plan (1991-1995), the other 12 experimental demonstration zones will be set up in the region, and these will be integrated with the regional characterization of soils and water by taking comprehensive measures, which will include identifying the instruments ratio of large-scale grain input and the monitoring of forest, grass and erosion systems, among other things. All these measures will lead to an increase of $30 \%$ in grain output and $50 \%$ in per capita income and a $30 \%$ decrease in running sand in the experimental demonstration zones. During the Seventh Fiveyear Plan (1985-1990) the per capita income in the Anshi Region, Northern Shannxi Province, was four times as much, while its grain yield per unit area 
was $30-70 \mathrm{~kg}$. This region is expected to be built up as a soil and water conservative and ecological agricultural base in 10 years.

\section{Control of alkalization. -}

By means of comprehensive control from 1983 to 1989, conducted in the alkali and saline soil districts of Fengqiu County, Henan Province, the grain output increased by $185 \mathrm{~kg}$ to $583 \mathrm{~kg}$, while the per capita income rose from 154 Yuan to 628 Yuan. At the same time, the grain yield per unit area in the Yucheng County of Shangdong Province increased by $200 \mathrm{~kg}$ to $700 \mathrm{~kg}$ after the control of alkali and saline soils. In accordance with a programme involving comprehensive control and reasonable adjustment of water resources, as well as the establishment of water resources in association with the establishment of ecological systems, this region, by the end of this century, will make it possible to enhance agricultural development, giving an output increment of 15 billion $\mathrm{kg}$ of grain, 1 million dan $(50 \mathrm{~kg})$ of cotton, 1.5 million ton of oil crops, and 2 million ton of meat.

\section{Control of fertility. -}

There are about 13 million hectares of arable land in the red soil hilly regions, in which land suffering from acidification, concretion and poor nutrition accounts for $60 \%$. But the area definitely has productive potential. The experience obtained from the Qianyan Zhou Experimental Zone has indicated that by means of integrated development based on the reclamation of 236 hectares of bare land, the total output value in the zone has increased from 580 Yuan to 390,000 Yuan, while the net income per capita has increased during six years (1983-1988) from 130 Yuan to 1078 Yuan. In the Yingtan Experimental Station, with the emphasis on soil and water conservation, soil fertilization and the establishment of a vertical layout of agriculture, pasture and animal husbandry, the grain output in 3 years increased from $500 \mathrm{~kg}$ to $1800 \mathrm{~kg}$ while the tea output doubled. In the Eighth Five-year Plan (1991-1995) 12 more demonstration zones will be set up in the red soil hilly regions, aiming to spread the experience obtained from the demonstration zones and comprehensively control soil degradation. The grain output will be expected to rise by as much as 20 billion kilograms, with a great development in economic crops in tropical and subtropical zones as well as an obvious improvement in soil and water conservation and ecological environments.

\section{Control of depression. -}

In the Three-River Plain (the Heilongjiang River, Wusulijang River and Songhuajiang River) in Northeast China there used to exist about 2.3 million ha of bog soils. Because of inadequate drainage, flood threat, soil fertility, degradation and low efficiency against natural diseases, the grain output in some cultivated areas was only slightly more than $1.5 \mathrm{t} / \mathrm{ha}$. 
By demonstrating and adopting comprehensive ways of utilizing rice growing, reed planting and fish cultivation in bog fields, the output of grain and reed has reached $10 \mathrm{t}$ and $2 \mathrm{t} /$ ha, respectively, and the output value of fish has doubled as well. During the Eighth Five-year Plan (1991-1995) several demonstration zones will be set up, including a wet soil ecological engineering project concentrating on the adjustment of water, in a bid to strengthen measures to improve soil fertility, which could lead to an increase of 200 Yuan, in the output value of grain in bog soils, while the output of grain in the region will increase from 2.5 billion to 5.0 billion kilograms.

Management of ecological systems. -

The comprehensive adjustment and management of forest and grass should be put into operation so as to strengthen the protection of different biological resources.

China contains $10 \%$ of the world fauna and $40 \%$ of the microbiological deposits, while China's biological diversification is 8 th in the world.

Protection of arable land and enforcing legislation and legal systems

Statistics have shown that China has only 31 million hectares of land resources in potential for action, of which 16 million ha will be used as pasture, 3 million ha for economic timber cultivation, 13 million ha for agriculture and 130,000 ha for coastal beach land. Under the situation of increasing population and decreasing land, arable land must be strictly prevented: one inch of land must be considered as valuable as one ounce of gold, in line with the operation of laws on land management.

In addition, the use of restrictive policies and legislative measures, such as the adoption of the forest law and laws on soil and water conservation is needed for both corrective and preventive land planning by means of strict control of the population increase and the alienation of farmland caused by human activities.

\section{Organization of key projects and expansion of research into land degradation}

In order to comprehensively prevent and control land degradation in China, an organization involving different departments should be set up, aiming to conduct resarch on "Changes and monitoring of China's land degradation in time and place to human existence and ecological systems". The detailed contents of this scientific and technical project are as follows.

1. The influence and feedback of human interactions on land degradation from the last century to recent decades. 
2. As regards the causes of secondary salinization, desertification, erosion and the processes of physical, chemical and biological degradation of soil fertility, including desertification in the dry arid regions and in the interlocking region of agriculture and pasture, soil erosion occurred in the Loess Plateau, soil erosion and bare land in the hilly regions of South China, and the degradation of land fertility in the main agricultural zones, such as the Songliao Plain, the North China Plain, the Taihu Lake Plain and the hilly areas to the south of the Yangtze River.

3. Studies on the evolutionary trends of land degradation. A model of land degradation and a data bank should be set up based on this research, so as to investigate the forecasting and monitoring of land degradation.

The project discussed above can be summarized in five main points, namely: the present and future situation of land degradation in China and ways of properly utilizing the ecological environments and of conserving soil and water in China; economic approaches, and policies; ecologically sensitive ecosystems involved in China's desertification; adjustment and exploitation of ecosystems in forests and grasslands; and studies on the variation of biological deposits, where five great zones can be considered, namely the red soil hilly zone, the Loess Plateau, the Huang-huai-hai Plain, the Three-River Plain, and the desert zone.

\section{Conclusions}

1. Land degradation is one of the greatest challenges facing China. With the population increasing and cultivated land decreasing, studies have shown that the greatest capacity of the land in China is a population of 1.6 billion, with $500 \mathrm{~kg}$ of grain per capita by the year 2050. Statistics show that in the early 50 's there was 0.2 ha of cultivated land per capita, while at present this figure is 0.11 ha per capita and is likely to be only 0.06 ha by the end of this century. On the other hand, there are about 13 million ha of cultivated land in China at present, of which nearly 3.3 million ha have been degraded because of unreasonable use. The relationship between population density and land reduction indicates an obvious shortage of land resources in China, a problem facing not only China but also the whole globe. The problem is extremely serious and is worthy of special attention.

2. Through long-term practice, China has accumulated an abundance of experience for the utilization of land resources and the prevention and control of land degradation. Land degradation can be overcome if comprehensive management is kept in line with the characteristics of the local natural conditions, following the principle of suiting the measures to different conditions and utilizing them in an all-round way. Policies should be implemented to strengthen the input as well as the adoption of science and technology. Our future looks bright. 
The experience gained in the prevention and control of land degradation in China has shown great significance for the whole world. As scientists we would like to call on all international communities and the respective governments to take immediate action for the preservation of land resources in order to prevent further land degradation, and to make contributions to human existence and ecological improvement. Our slogan should be "Control land degradation and save land resources, which means saving man himself". 